\title{
Introduksi Pembuatan Pakan dari Bahan Alternatif Pering Kelapa untuk Menunjang Budidaya Ikan
}

\section{Introduction on Farm Feed from Alternative Materials of Coconut Husk to Support Fish Cultivation}

\author{
Kiki Haetami $^{1, a}$, Junianto ${ }^{1}$, Abun $^{2}$, Yuniar Mulyani ${ }^{1}$ \\ ${ }^{1}$ Fakultas Perikanan dan Ilmu Kelautan, Universitas Padjadjaran Bandung \\ ${ }^{2}$ Fakultas Peternakan, Universitas Padjadjaran Bandung \\ aemail: kiki.haetami@gmail.com
}

\begin{abstract}
Abstrak
Masyarakat petani di Desa Margaasih dengan unit kelompok Sugih Mukti berperan penting sebagai pelaku ekonomi bidang pertanian. Lokasi desa yang tidak jauh dari pusat Kecamatan Cicalengka termasuk pasar tradisional, sehingga sub-sektor perikanan dan peternakan berpeluang ditingkatkan, dengan memanfaatkan limbah pertanian maupun limbah pasar sebagai sumber pakan. Kegiatan pengabdian masyarakat dilakukan untuk transfer pengetahuan pakan alternatif dari limbah pering kelapa sebagai introduksi kearah pembuatan pakan sendiri sebagai upaya menunjang budidaya ikan di pekarangan. Respon masyarakat secara pastisipatif diwakili oleh pembudidaya dan pengurus kelompok tani khusunya UPT Sugih Mandiri yang mengelola alat mesin pertanian. Respon positif dari masyarakat Dusun Ciseuereuh ditunjukkan dengan minat untuk memelihara ternak-ikan di pekarangan dan keikut sertaannya dalam praktek formulasi dan membuat pakan. Pering kelapa dan bahan alternative lainnya berpeluang sebagai bahan baku pembuatan pakan mandiri (on-farm feed) sebagai bahan pakan pengisi (filler) untuk mengurangi ketergantungan pada pakan komersial.
\end{abstract}

Kata Kunci: Introduksi, Budidaya, Bebasis Muatan Lokal, Pering Kelapa, Pakan Ikan.

\begin{abstract}
The farming community in Margaasih village with the Sugih Mukti group unit plays an important role as economic factors in the agricultural sector. The village location which is not far from the center of Cicalengka District is a traditional market so that the fisheries and livestock sub-sector have the opportunity to be improved, by utilizing agricultural waste and market waste as a source of feed. Community service activities are carried out to transfer knowledge of alternative feeds from coconut husk waste as an introduction towards making their own feed as an effort to support fish cultivation in the yard. The community's response was participatory in a way that was represented by the cultivators and the management of farmer groups, especially UPT Sugih Mandiri who managed agricultural machinery. The positive response from the people of Ciseuereuh Hamlet was shown by their interest in raising fish in the yard and their participation in the practice of formulating and making feed. Coconut husk and other alternative materials have the opportunity to be used as raw material for the manufacture of independent feed (on-farm feed) as a filler to reduce dependence on commercial feed.
\end{abstract}

Keywords: Introduction, Cultivation, Local Content-Based, Coconut Husk, Fish Feed.

\section{Pendahuluan}

Ikan adalah pangan bergizi yang berniai tinggi, sebagai salah satu bahan makanan yang menjadi sumber protein, untuk menunjang kesehatan dan kecerdasan manusia. Kementerian Pertanian telah menginisiasi program Obor Pangan Lestari (OPAL) yaitu program yang mengajak 
masyarakat untuk memanfaatkan lahan pekarangan dan menghasilkan sumber pangan untuk gizi keluarga. Budidaya ikan memang dapat dilakukan sedemikian rupa mengikuti sumber daya yang tersedia. Usaha budidaya ikan lele, ikan mas dan nila sudah mulai digalakkan ke arah intensifikasi termasuk melalui penggalakan kolam sistem karpet di pekarangan. Permasalahan yang dijumpai oleh pembudidaya adalah mahalnya harga pakan ikan yang jika ditotal selama masa budidaya, mencapai $60-75 \%$ dari biaya produksi (Ensminger, 1990). Oleh karena itu, pembudidaya perlu memiliki inovasi, salah satunya adalah dengan membuat pakan ikan sendiri.

Usaha introduksi ini meliputi alih penegetahuan potensi lokal dan formulasi secara sederhana dengan memanfaatkan sumber daya alam yang ada meliputi limbah pering kelapa, penggilingan padi (dedak), dan limbah ikan, melalui teknik fermentasi pembuatan pakan ikan berbasis muatan lokal.

Pelaksanaan penyuluhan dan
introduksi ini diharapkan dapat
meningkatkan pengetahuan petani mengenai formulasi pakan dan penyederhanaan proses pembuatan, agar praktis secara ekonomis bagi pengguna dan dapat mengurangi ketergantungan akan pakan komersial.

Tujuan introduksi mengolah pakan sendiri adalah mengenalkan dan bertukar pengetahuan dengan pengelola UPT Sugih Mandiri, Desa Margaasih, Kecamatan Cicalengka, Kabupaten Bandung dan inovasi serta proses pembuatan pakan dari bahan limbah pering kelapa untuk menunjang budidaya ikan. Manfaat kegiatan ini secara tidak langsung mendukung program OPAL (Kementerian Pertanian, 2019) yaitu mengembangkan budidaya dan membuat pakan ikan untuk mendukungnya dalam rangka pemanfaatan pekarangan. pengetahuan tentang pakan alternatif. Tujuannya adalah agar pengeluaran untuk pembelian pakan dapat berkurang. Bahan-bahan yang diperlukan untuk pembuatan pakan alternatif bisa diperoleh di sekitar wilayah Cicalengka, salah satunya pering kelapa yang menjadi limbah di pasar-pasar, serta bahan limbah hewani seperti kepala ikan/udang,
Pemberian pakan alami sumber protein seperti cacing dan tubifek seringkali dilakukan secara langsung (tidak perlu diolah) sebagai makanan jenis ikan tertentu seperti lele, mujair, dan gurame, namun perlu dibantu dengan ketersediaan pellet komersil sebagai bahan pengisi. Saat ini, pakan komersial semakin bersaing dan mahal apabila bahan baku yang tersedia dapat dicari dan diupayakan, maka introduksi pengolahan pakan sendiri menjadi pellet menjadi penting dilakukan. Keberadaan Kelompok Tani Sugih Mukti di Desa Margaasih (Data Potensi Desa, 2019), dan UPT Sugih Mandiri yang mengelola alat mesin pertanian sebagai bagian dari unit kerja kelompok tani, dapat digerakkan untuk memproduksi pakan ikan sendiri (on-farm feed). Cara pengolahannya yaitu dengan dijadikan tepung terlebih dahulu kemudian dicampur bahan-bahan lain seperti tepung jagung untuk perekat dan protein lainnya kemudian di masukan ke dalam mesin pelet, hingga akhirnya dapat diberikan kepada ikan (Amalia dkk., 2018).

\section{Materi dan Metode Pelaksanaan}

Tujuan pengelolaan pakan adalah meningkatkan efisiensi penggunaan bahan baku, mengurangi limbah pakan, meningkatkan kualitas pakan, dan memperbaiki penyediaan pakan. Pembuatan pakan murah akan diupayakan dengan memanfaatkan bahan dari limbah pertanian yang ada di sekitar sentra produksi ikan air tawar. Sistem usaha ke arah intensif di bidang pembesaran ikan dikolam bundar terpal tidak membutuhkan air mengalir dalam pemeliharaannya (Susanto, 2004). Jika memilih wadah budidaya dari terpal dengan ukuran kurang lebih 5x2 meter, maka dapat diisi kapasitas 1.000 ekor ikan nila (BRPBAT, 2003).

Ketergantungan akan pakan komersial menambah biaya (ongkos) produksi, hingga $75 \%$ (Ensminger, 1990). Beralihnya fungsi lahan menjadikan intensifikasi perikanan pada lahan sempit yang pernah digalakkan di Desa Margaasih terkendala oleh mahalnya ongkos produksi dari pakan. Dukungan usaha pakan ikan mandiri untuk menekan biaya pakan komersil sangat urgen untuk 
direalisasikan. Potensi bahan asal limbah warung makan, dan limbah pabrik (penggilingan padi dan tahu) di sekitar wilayah ini dapat diolah sebagai pakan alternatif. Oleh sebab itu, dipandang perlu untuk memberikan penyuluhan dan pelatihan mengenai teknik fermentasi bahan pakan dan formulasi pakan untuk diolah menjadi pelet ikan.

Salah satu cara untuk menekan biaya pakan adalah membuat sendiri pellet dengan bahan baku pakan murah untuk diformulasikan sesuai dengan kebutuhan ikan menjadi pellet ikan berkualitas. Namun, masalah yang ada pada limbah pasar seperti pering kelapa adalah berkadar air tinggi, berprotein rendah, namun mengandung serat kasar yang tinggi, sehingga perlu proses pengolahan. Transfer ilmu tentang pengenalan teknik fermentasi, pengadaan bahan baku pakan, formulasi pakan dan teknik pembuatan pellet, dengan kesadaran dan kemampuan bahwa kondisi lebih baik yang diharapkan dapat diupayakan untuk dicapai, yaitu melalui proses adopsi inovasi dengan penyuluhan dan pelatihan.

\section{Metode}

Daring (dalam jaringan) adalah metode yang dilaksanakan secara interaktif menggunakan jaringan internet, meggunakan berbagai platform seperti Zoom Claud Meetin dan Google Meet untuk menunjang kegiatan PPM di tengah masamasa pandemi ini. Metode Luar Jaringan (Luring) dilaksanakan dengan mengunjungi Desa Margaasih Kecamatan Cicalengka Kabupaten Bandung yang diwakili oleh perwakilan kelompok metode luring yang digunakan diantaranya:

\section{Observasi}

Observasi atau pengamatan adalah pengumpulan data yang dilakukan dengan cara mengamati dan mencatat sistematis potensi perikanan di Desa Margaasih. Observasi dilakukan dengan terjun langsung untuk mengamati secara langsung kondisi Desa Margaasih untuk melihat potensi perikanan di desa tersebut.

\section{Wawancara}

Metode interview atau yang sering disebut wawancara, yaitu suatu metode pengumpulan data yang dilakukan melalui tanya jawab secara langsung dari sumber data. Kegiatan interview terhadap perwakilan anggota kelompok tani Sugih Mukti yang diketuai kepada Pak Ajang yang bertujuan untuk memperoleh informasi yang ada relevansinya dengan topik PPM yaitu mengenai budidaya dan pembuatan pakan.

\section{Tahapan Pelaksanaan}

- Persiapan webinar "Pengenalan Pakan untuk Menunjang Budidaya Ikan".

- Juli 2020 observasi manajemen pengelolaan air untuk wadah budidaya ikan, jenis wadah budidaya ikan dilahan terbatas, jenis pakan alternatif untuk ikan, pembesaran lele, dan pembesaran nila.

- Mempersiapkan video pembuatan pakan alternatif dari pering kelapa.

- Pelaksanaan Daring dan Luring

- Praktek pengolahan pering kelapa dan pembuatan pellet

\section{Lokasi dan Sasaran}

Lokasi dan sasaran adalah di Desa Margaasih dengan sasaran pengurus UPT Sugih Mandiri agar terdapat saling berinteraksi dan bertukar pikiran tentang potensi ataupun strategi yang mungkin dapat dilakukan sehingga mampu memberi manfaat bagi masyarakat pembudidaya ikan di desa Margaasih, Kecamatan Cicalengka, Kabupaten Bandung. Sosialisasi dan pembuatan pakan ikan dan pakan alternatif dengan teknik fermentasi oleh Kelompok Tani Sugih Mukti sub unit kerja UPT Sugih Mandiri 


\section{Hasil dan Pembahasan}

Hasil penjajakan dan observasi melalui wawancara mengenai preferensi minat masyarakat budidaya ikan di wilayah kerja kelompok tani Sugihmukti ternyata memiliki kolam budidaya ikan, disamping peternakan sapi, ayam dan usaha pertanian lainnya. Mahalnya harga pakan ikan dan menjadi kendala, pemanfaatan bahan limbah untuk pakan ikan belum banyak dikenal, khususnya teknik pembuatan pellet ikan masih kurang, maka dari itu diperlukan transfer pengetahuan (Tarya, 1999), mengenai pentingnya perhatian terhadap pengadaan dan pemberian pakan.

Tokoh masyarakat dalam hal ini pengurus kelompok tani, khususnya UPT Sugih Mandiri, yang berlokasi di kampung Ciseureuh, bersama tim mendiskusikan tentang membuat pakan sendiri (on-farm feed). Langkah terpenting dari suatu pengabdian adalah pengaplikasian. Tidak hanya berdiskusi mengenai teori-teori seputar topik pembahasan, lebih dari itu masyarakat membutuhkan kejelasan dan pemahaman secara aplikatif. Lebih luas dari itu, masyarakat dan organisasi-organisasi yang bergerak dibidang perikanan juga dapat mendirikan budidaya ikan terintegrasi bersama untuk memproduksi pakan sendiri. Jika masyarakat memiliki kolam ikan sendiri, maka sedikit banyak kebutuhan protein akan terpenuhi, meskipun skala budidayanya masih sangat kecil. Selain itu, melalui kolaborasi itulah akan tercipta keselarasan dan saling memberi manfaat antar masyarakat atau kelompok satu sama lain.

Hasil dialog dan pretest yang dilakukan dengan beberapa petani-ikan dapat terungkap bahwa pengetahuan mengenai formulasi pakan ikan masih kurang. Hal ini terbukti bahwa petani-ikan di desa ini hanya mengandalkan pakan alami yang tersedia di kolam dan limbah rumah tangga, belum banyak yang menggunakan tambahan pelet atau konsentrat sebagai pakan utama. Demikian pula mengenai pengolahan pakan alternatif hasil fermentasi limbah perlu diintroduksikan sebagai penunjang tersedianya pakan awet dan berkualitas.

Tabel 1. Pelaksanaan Kegiatan Introduksi

\begin{tabular}{|c|c|c|}
\hline Waktu & Tahap & Kegiatan \\
\hline Minggu ke-1 & Persiapan & $\begin{array}{l}\text { Penyusunan materi PPM } \\
\text { - Identifikasi subjek, masalah, dan sumberdaya } \\
\text { untuk kegiatan PPM } \\
\text { - Survey ke pasar tradisional terhadap potensi } \\
\text { limbah pering kelapa } \\
\text { - Pengumpulan data tentang Desa Margaasih, } \\
\text { berkunjung ke kantor desa, kelompok tani, dan } \\
\text { tokoh masyarakat pembudidaya ikan }\end{array}$ \\
\hline Minggu ke-2 & & $\begin{array}{l}\text { Pengumpulan bahan baku pakan dan pering kelapa dan } \\
\text { alat peraga untuk penyuluhan }\end{array}$ \\
\hline Minggu ke-3 & & Kunjungan ke desa, persiapan untuk penyuluhan \\
\hline Minggu ke-4 & & $\begin{array}{l}\text { - Pembuatan poster, formulir, dan lain-lain untuk } \\
\text { menunjang penyuluhan virtual } \\
\text { - Penyusunan Materi }\end{array}$ \\
\hline \multirow[t]{2}{*}{$\begin{array}{l}\text { Minggu } \\
\text { ke-5-8 }\end{array}$} & $\begin{array}{l}\text { Pelaksanaan/ } \\
\text { Lapangan }\end{array}$ & $\begin{array}{l}\text { Pelaksanaan kegiatan PPM yaitu penyuluhan virtual } \\
\text { melalui Zoom }\end{array}$ \\
\hline & $\begin{array}{l}\text { Pascapelaksanaan/ } \\
\text { lapangan }\end{array}$ & $\begin{array}{l}\text { Praktek pembuatan pakan alternatif dan pellet ikan } \\
\text { berbasis pering kelapa; dan evaluasi, secara } \\
\text { partisipatif }\end{array}$ \\
\hline
\end{tabular}


Tabel 2. Indikator dan Pencapaian Introduksi Pakan untuk menunjang Budidaya Ikan

\begin{tabular}{|c|c|c|c|}
\hline No. & Metode kegiatan & Indikator keberhasilan yang diukur & Pencapaian \\
\hline 1. & $\begin{array}{l}\text { Penyuluhan } \\
\text { pentingnya } \\
\text { Budidaya Ikan }\end{array}$ & $\begin{array}{l}\text { 1. Transfer pengetahuan bagi } \\
\text { pembudidaya } \\
\text { 2. Mencoba membuat kolam } \\
\text { terpal }\end{array}$ & $\begin{array}{l}\text { UPT Sugih Mandiri } \\
\text { mempraktekan dan membuat } \\
\text { percontohan kolam terpal } \\
\text { bundar }\end{array}$ \\
\hline 2. & $\begin{array}{l}\text { Introduksi } \\
\text { Pembuatan Pakan }\end{array}$ & $\begin{array}{l}\text { 1. Memanfaatkan pering kelapa } \\
\text { hasil fermentasi sebagai bahan } \\
\text { pakan } \\
\text { 2. Mengurangi pemberian pakan } \\
\text { komersil }\end{array}$ & $\begin{array}{l}\text { Pembudidaya dan UPT Sugih } \\
\text { Mandiri mengenal bahan } \\
\text { limbah yang dapat diolah } \\
\text { menjadi alternative penyusun } \\
\text { pakan ikan }\end{array}$ \\
\hline
\end{tabular}

Langkah persiapan terdiri atas:

(1) Menghimpun dan memilih keputusan yang relevan.

(2) Persiapan alat bantu penyuluhan, seperti gambar-gambar yang dapat menunjang terhadap komunikasi visual.

(3) Persiapan alat dan bahan pembuatan pakan alternatif melalui teknik silase

(4) Persiapan alat dan bahan pembuatan pelet ikan, yaitu mesin pembuat pelet sederhana (alat penggiling daging), tampah, dan bahan baku pakan.

Selain persiapan alat dan bahan untuk pembuatan pakan, juga persiapan alat peraga contoh cara meracik (menyusun formula) ransum dari bahan lokal yang sesuai untuk kebutuhan ikan. Penyuluhan dilengkapi dengan:

(1) Demonstrasi pengolahan bahan pakan dan pembuatan pelet ikan dengan bahan seperti pering kelapa, tepung jagung, ragi oncom, tepung ikan, dedak padi, tampah, kantung plastik, air. Alat peninjang praktek adalah waskom, fermentor, pengaduk, tampah, dan pencetak pellet.

(2) Selain persiapan alat dan bahan untuk fermentasi pering kelapa dan pembuatan pakan, juga persiapan alat peraga contoh cara meracik (menyusun formula) ransum dari bahan lokal yang sesuai untuk kebutuhan ikan.

Uji coba budidaya ikan lele dalam kolam terpal dan pembuatan pakan alternatif untuk menunjang dan menekan biaya produksi dalam budidaya ikan di Desa Margaasih, dilaksanakan oleh perwakilan Kelompok Tani. Respon baik ditunjukan dengan membantu kelancaran proses penyuluhan, aktif bertanja-jawab sehingga proses introduksi pembuatan pakan ikan dapat berlangsung baik (Tabel 2).

Tabel 3. Indikator keberhasilan Kegiatan

\begin{tabular}{|c|c|c|c|}
\hline No. & Indikator & $\begin{array}{l}\text { Base line } \\
\text { (sebelum kegiatan) }\end{array}$ & $\begin{array}{l}\text { Pencapaian setelah } \\
\text { kegiatan }\end{array}$ \\
\hline 1. & $\begin{array}{l}\text { Peningkatan pemahaman } \\
\text { pentingnya membuat pakan } \\
\text { sebagai penunjang budidaya }\end{array}$ & $\begin{array}{l}\text { Kurang pengetahuan } \\
\text { tentang pakan } \\
\text { alternative dan } \\
\text { pembuatannya }\end{array}$ & $\begin{array}{l}\text { Ada perubahan } \\
\text { pengetahuan dan } \\
\text { keterampilan membuat } \\
\text { pakan asal limbah }\end{array}$ \\
\hline 2. & $\begin{array}{l}\text { Jumlah pakan alternative } \\
\text { dan adanya } \\
\text { pemanfaatan }\end{array}$ & $\begin{array}{l}\text { Terbatasnya } \\
\text { pengetahuan pakan } \\
\text { dan penggunaannya }\end{array}$ & $\begin{array}{l}\text { Penambahan wawasan } \\
\text { tentang pakan dan } \\
\text { pengolahannya }\end{array}$ \\
\hline 3. & Kelembagaan & Kurang aktif & $\begin{array}{l}\text { Diaktifkan dengan upaya } \\
\text { pengadaan pabrik pakan } \\
\text { skala kecil }\end{array}$ \\
\hline
\end{tabular}


Keberhasilan kegiatan Pengabdian kepada Masyarakat dievaluasi dengan melihat respon yang diberikan oleh peserta kegiatan, yang diukur melalui:

1. Perubahan pengetahuan mengenai teknik formulasi pakan dengan menggunakan bahan baku pakan lokal.

2. Perubahan pengetahuan mengenai teknik dan pembuatan pakan ikan.

3. Sampai berapa jauh peserta dapat melaksanakan teknik pembuatan pakan alternatif dengan mengolah limbah lokal secara teknologi sederhana

Kegiatan pengabdian pada masyarakat yang dilakukan di Desa Margaasih ini dapat dikatakan cukup mendapat partisipasi dari masyarakat setempat, khususnya para petani-ikan. Kegiatan ini didukung oleh partisipasi aktif dari ketua kelompok taniikan "Sugih Muti" dan kepala dusun Ciseureuh temmpat lokasinya UPT Sugih Mandiri. Partisipasi juga tidak hanya dalam bentuk partisipasi penyuluhan daring dan demontrasi plot, tetapi aktif berkomunikasi atau berdialog mengenai pakan.

Salah satu aspek yang mendapat perhatian dari para peserta adalah cara pengolahan limbah pertanian menjadi bahan baku pakan yang efisien menuju pembuatan pakan mandiri. Menurut De Silva (1993), limbah pertanian dapat dijadikan bahan baku pakan ikan. Dengan ditemukannya inovasi ini diharapkan dapat menekan biaya pakan, serta kebutuhan zat makanan untuk ikan ikan cukup memadai.

Hasil kegiatan penyuluhan dan keterampilan setelah dilakukan post test, dapat diketahui bahwa:

(1) Pengetahuan (kognitif) masyarakat tentang meramu pakan ikan sendiri meningkat, dari hasil Tanya jawab saat kegiatan.

(2) Keterampilan pengolahan pakan alternative asal limbah meningkat $50 \%$, yang terukur dari dari partisipasi aktif melakukan praktek pengolahan pakan.

(3) Pengetahuan formulasi dan manajemen pemberian pakan ikan meningkat dengan adanya partisipasi aktif saat penyululuhan.

(4) Terangsangnya kembali aktifitas kelompok tani sub bidang perikanan untuk mengembangkan usahanya. Hal ini terlihat dari dukungan pengurus untuk memayarakatkan budidaya lele dan nila melalui kolam sistem karpet dengan pasokan pakan yang dikelola oleh UPT Sugih Mandiri. Ketersediaan bahan pakan berbasis local meningkat dengan bertambahnya inventaris bahan baku local dari hasil limbah agroindustri dan limbah pasar, yaitu pering kelapa.

\section{Kesimpulan dan Saran}

Kegiatan introduksi pembuatan pakan melalui transfer pengetahuan sumber pakan alternatif dapat menjadi kunci awal minat masyarakat dalam budidaya ikan. Pengetahuan petani-ikan mengenai pengolahan dan formulasi pakan dan didukung dengan praktek pelatihan dapat menunjang minat membuat pakan sendiri dalam menunjang budidaya ikan.

Budidaya ikan secara intensif melalui introduksi teknik formulasi dan pembuatan pakan di Desa Margaasih dapat dimasyarakatkan, maka perlu adanya tindak lanjut kegiatan Pengabdian Pada Masyarakat mengenai optimalisasi produksi pakan sendiri (on-farm feed).

\section{Daftar Pustaka}

Amalia R, Amrullah, dan Suriati. 2018. Manajemen Pemberian Pakan Pada Pembesaran Ikan Nila (Oreochromis niloticus). Sinergitas Multidisiplin Ilmu Pengetahuan dan Teknol. 2018;1(1):252-7.

BRPBAT (Balai Riset Perikanan Budidaya Air Tawar). 2003. Aplikasi Teknologi Pakan dan Perkembangan Usaha Perikanan Budidaya. Prosiding Semiloka. ISBN: 979-8186-91-1. Pusat Riset Perikanan Budidaya. Badan Riset Kelautan dan Perikanan. Departemen Kelautan dan Perikanan.

Devani V, Basriati S, Devani V, Studi P, Industri T, Sains F. Optimasi Kandungan Nutrisi Pakan Ikan Buatan dengan Menggunakan Multi Objective 
(Goal) Programming Model. Sains, Teknol dan Ind. 2015;12(2):255-61.

Dozier, W.A. 2001. Pellet Quality for Most Economical Poultry Meat. Feed Management 52(2). Watt Publishing Co, MT Morris III.

Data Monografi Desa. 2019. Desa Margaasih, Cicalengka. Kabupaten DT II Bandung. Jawa Barat.

De Silva. S.S. 1993. Finfish Nutrition Research in Asia. Proceeding of second sian Fish Nutrition Network Meeting. Heinemann Asia. Singapore.

Ensminger, M.E., J.E. Oldfield, dan W.W. Heinemann, 1990. Feed and Nutrition. Second Edition.The Ensminger Publishing, Co.

Kementrian Pertanian. Panduan Obor Pangan Lestari (OPAL) Tahun 2019.

Tarya, J.S. 1999. Dasar-dasar Ilmu Penyuluhan Pertanian. Badan Penerbit dan Bursa Buku. Fakultas Pertanian, Universitas Padjadjaran. 